\title{
Long-Term Effects of COVID-19 on Adolescents
}

\author{
COVID-19'un Adölesanlar Üzerindeki Uzun Dönem Etkileri
}

\section{${ }^{1}$ Merve Iseri Nepesov, ${ }^{2}$ Ozge Avsar, ${ }^{2}$ Erdal Sari, ${ }^{2}$ Rabia Gonul Sezer Yamanel}

${ }^{1}$ Department of Pediatric Infectious Diseases, University of Health Sciences, Zeynep Kamil Maternity and Children's Hospital, Istanbul, Turkey

${ }^{2}$ Department of Pediatrics, University of Health Sciences, Zeynep Kamil Maternity and Children's Hospital, Istanbul, Turkey

Correspondence:

Merve ICERI NEPESOV

Department of Pediatric Infectious

Diseases, University of Health

Sciences, Zeynep Kamil Maternity

and Children's Hospital, Istanbul,

Turkey

e-mail: iserimerve@yahoo.com

\section{Abstract}

Long-term effects are increasingly reported in adult patients with coronavirus disease-2019 (COVID-19) but there are not enough studies in adolescents. This study aimed to evaluate the long-term effects of COVID-19 in the adolescent population. Adolescent patients diagnosed with non-severe COVID-19 between October 2020 and January 2021 in our center were questioned in terms of long-term effects by telephone call. A total of 109 adolescent patients with non-severe COVID-19 were evaluated. In five of them at least of one myalgia/fatigue, cough, chest pain, palpitation, sleep disorderand psychiatric problems are seen as long冈term effects of COVID-19. These five patients had a median age of 16.4 years (range 11.5-17) and three of them are boys. The mean time that we evaluate these patients after diagnosis is $121.6 \pm 13.1$ days. All of them categorized as 'mild' COVID-19 infection and none of them were hospitalized. Only one patient has the underlying disease 'asthma'. Long-term COVID-19 symptoms can also be seen in otherwise healthy children after mild disease. Especially psychiatric complaints should not be ignored and pediatricians should be more careful in terms of these effects.

Keywords: adolescent, coronavirus, long COVID-19, pandemic, Turkey

\section{Özet}

Yeni koronavirüs hastalığı-2019 (COVID-19) geçiren yetişkin hastalarda uzun dönem etkiler, giderek daha fazla bildirilmekte ancak adölesanlarda konuyla ilgili yeterli çalışma bulunmamaktadır. Bu çalışma, COVID-19'un adölesan hasta grubunda uzun vadeli etkilerini değerlendirmeyi amaçlamıștır. Merkezimizde Ekim 2020-Ocak 2021 tarihleri arasında ağır olmayan COVID-19 tanısı alan adölesan hastalar telefonla aranarak uzun dönem etkiler açısından sorgulandı. Ağır olmayan COVID-19 tanısı alan 109 adölesan hasta çalışmaya dahil edildi. Bu hastaların beşinde miyalji/yorgunluk, öksürük, göğüs ağrısı, çarpıntı, uyku bozukluğu ve psikiyatrik sorunların en az biri COVID-19'un uzun dönem etkileri olarak görüldü. Bu beş hastanın medyan yaşı 197 ay (138-204) olup üçü erkekti. Tanı konulduktan sonra hastaların değerlendirildiği ortalama süre 121,6 $\pm 13,1$ gündü. Tümü 'hafif' COVID-19 enfeksiyonu tanısı almıs olup hiçbirinin hastane yatıs öyküsü yoktu. Sadece bir hastada altta yatan hastalık 'astım' vardı. Uzun dönem COVID-19 semptomları, öncesinde sağlıklı olan adölesanlarda hafif hastalık kliniğinden sonra görülebilir. Özellikle psikiyatrik şikayetler göz ardı edilmemeli ve çocuk doktorları bu etkiler konusunda daha dikkatli olmalıdır.

Anahtar Kelimeler: koronavirüs, uzun COVID-19, adölesan, pandemi 


\section{Introduction}

Since December 2019, the world has been dealing intensively with a newly identified infectious disease named COVID-19 caused by severe acute respiratory syndrome coronavirus 2 (SARS-CoV-2).1,2 Although the knowledge on the clinical course of the disease increases day by day, there are still many unknowns.

The clinical course of the disease varies from asymptomatic to severe respiratory failure.3,4It seems to have less severe course in children than adults with good prognosis but recently, complications related to COVID19 were reported.3-5One of these is multisystem inflammatory syndrome in children (MIS-C) and the other one is longterm COVID-19 associated signs and symtoms.5-7Although MIS-C criteria and treatment method are increasingly included in the literature, the data examining the longterm effects of COVID-19 in the pediatric patient group are very limited.7-9 Adolescence is a special period, COVID-19 pandemic and the measures taken in this direction has negative effects on adolescent health but it is a question of how these effects will be who have had COVID 19.10In this study, we aimed to investigate the presence and duration of long term symptoms related to COVID-19 in adolescents.

\section{Material and Methods}

Adolescent patients diagnosed with nonsevere COVID 19 infection between October 2020 and January 2021 in the University of Health Sciences, Zeynep Kamil Maternity and Children's Hospital were included in this cross-sectional retrospective study. The definition of adolescent was defined according to WHO and patients between the ages of 10-18 were included.11Patients with negative PCR results or severe COVID-19 were excluded from the study.

In our study, only the patients that the diagnosis was confirmed by positive real-time reverse transcriptase-polymerase chain reaction from nasopharyngeal swabs were included. Real-time PCR diagnostic kits authorized by the General Directorate of Public Health (GDPH) Microbiology
Reference Laboratory were used for the diagnosis.12In addition, only patients classified as asymptomatic, mild or moderate were included in the study. Patients were categorized according to the features defined by Dong et al. such as, the patients with no signs or symptoms were defined as 'asymptomatic', patients with symptoms of acute upper respiratory tract infection but without pneumonia as 'mild', presence of pneumonia but with no obvious hypoxemia as 'moderate'.13

Post COVID-19 patients were called by phone and a questionnaire was applied to their parents. In the questionnaire, the presence of symptoms throughout illness and whether any complaints are still present were asked. If the patient has an ongoing complaint, whether it affects his/her daily activities and school life, or whether there is a clinic visit for this is questioned. Also, whether there was a change in sleep patterns that did not exist before COVID 19 infection was questioned with the following three questions: Is he/she having trouble with falling asleep? Does he/she wake up often? Has there been a change in total sleep time?

A review of data on the demographics, clinical, laboratory, radiological, treatment, and outcomes was recorded. Clinical data were extracted from medical records, which included age, sex, underlying disease, presenting symptoms, exposure history, leucocyte, lymphocyte and thrombocyte count. The leucocyte and lymphocyte count levels were determined by comparison with our local age-related normal ranges.14Thrombocytopenia was defined as thrombocyte count below $150,000 / \mathrm{mm} 3$; while neutropenia was defined as neutrophil count $<1,500 / \mathrm{mm} 3$.

All procedures performed in studies involving human participants were in accordance with the Helsinki Declaration. Approval for the study was obtained from the local ethics committee of University of Health Sciences, Zeynep Kamil Maternity and Children's Hospital (March 2021-78). 


\section{Statistical analysis}

The statistical package SPSS version 15.0 (IBM SPSS Statistics, Chicago, IL) was used for data analysis. Quantitative variables were expressed as mean ( \pm standard deviation) or median values, while qualitative variables were expressed as percentages.

\section{Results}

There were 124 adolescents diagnosed with COVID-19 during the study period. All the patients were called by phone, 109 of them were contacted and their families were interviewed. Fifty six $(51.4 \%)$ of the patients were male and $53(48.6 \%)$ were female. Among patients, the mean age $( \pm \mathrm{SD})$ was $14.4( \pm 2)$ years. There was no history of chronic disease in $95.4 \%$ (104) of the patients. Comorbidities such as congenital hypothyroidism, asthma, dyslexia, ulcerative colitis, and atrial septal defect were present in five patients.

Of the 109 patients, $75.2 \%$ had an exposure history with an infected family member, $17.5 \%$ had contact with a friend with COVID19 , while $7.3 \%$ of patient had no history of contact.

Seven (6.4\%) patients were asymtomatic. Among the complaints on admission fever was present in $27.5 \%$ of cases. The most common symptoms were fatigue/myalgia $(46.8 \%)$ and cough $(33.9 \%)$ followed by headache $(20.2 \%)$, sore throat $(18.3 \%)$, ageusia $(11.9 \%)$, anosmia $(7.3 \%)$,rhinorrhea (4.6\%), diarrhea (2.8\%), dyspnea $(2.8 \%)$, chest pain (1.8\%), conjunctivitis $(1.8 \%)$ abdominal pain $(0.9 \%)$, vomiting $(0.9 \%)$, and $\operatorname{rash}(0.9 \%)$.

Analysis of blood tests was available for 19 $(17.5 \%)$ children at the time of diagnosis. The median WBC was 5730 (3690-16300) cells/mm3, neutrophil was 3590 (2060-13500) cells/mm3, lymphocytewas 1610 (880-2680) cells/mm3. Lymphopenia, leukopenia, and leukocytosis were identified in $9.2 \%, 2.8 \%$ and $0.9 \%$ of patients, respectively. Increased levels of C-reactive protein (CRP) were detected in five patients.
Seven $(6.4 \%)$ of the patients were classified as 'asymptomatic', 101 (92.7\%) as mild, one $(0.9 \%)$ as 'moderate'. Only one patient were admitted to the hospital with diagnosis of pneumonia and length of stay in the hospital was 3 days.

We found ongoing symptoms or complaints in five patients. When these 5 patients and asymptomatic patients were excluded from the group, the average duration of symptoms related to COVID-19 was $3.6 \pm 2.3$ days.

In patients with ongoing symptoms, the mean of time that we evaluate patients after diagnosis is $121.6 \pm 13.1$ days. The median age of these patients was 16.4 (11.5-17) years while two of them were girls. All of them categorized as 'mild' COVID-19 infection and none of them were hospitalized. Only one patient has underlying disease 'asthma'.

One patient after 132 days from the diagnosis described cough, chest pain, palpitation, myalgia/fatigue. For this reason, she has visited pediatric clinics four times and was also evaluated by a pediatric cardiologist. The chest x-ray was normal. Electrocardiography showed a normal sinus rhythm with no abnormalities. In echocardiographic evaluation mitral valve prolapsus and mild mitral regurgitation were seen. She also had fear of not being able to breathe and pessimism. In this respect, the patient, who was evaluated by a child psychiatrist, was included in the psychotherapy program with the diagnosis of anxiety and mild depressive symptoms. All of her current complaints began after she had a COVID-19 infection.

The second patient who has also underlying asthma history has ongoing dyspnea and myalgia/fatigue. She can continue to do daily activities but she was unable to work because she could not stand for a long time while working in a clothing store as part-time work before COVID-19. The patient visited the pediatric outpatient clinic once with these complaints, and her physical examination and laboratory results were normal.

One patient continues to suffer from myalgia/fatigue but he carries out his daily activities and follows all of the school lessons 
online. He also has serious concerns about going out that he went out only 4 times in the past five months after the diagnosis. The patient, who plays violin and piano and was very enthusiastic about music education quit lessons after COVID-19 with fear of going out. He is also having trouble with falling asleep and wakes up frequently at night. Although the family thought it was necessary to visit the psychiatry clinic, he did not accept.
The other two patients complained of myalgia/fatigue even they go on to do their daily activities. These two patients similarly stated that they did not want to go out or school with fear of reinfection. One of these patients had a child psychiatry visit. Detailed characteristics of the patients are presented in Table 1.

Table 1. Characteristics of the peditric patients with long term effects of COVID-19

\begin{tabular}{|c|c|c|c|c|c|}
\hline & Patient 1 & Patient 2 & Patient 3 & Patient 4 & Patient 5 \\
\hline $\begin{array}{l}\text { Gender, age at } \\
\text { diagnosis }\end{array}$ & $\begin{array}{l}\text { Female, } \\
16.8 \text { years }\end{array}$ & $\begin{array}{l}\text { Female, } \\
17 \text { years }\end{array}$ & $\begin{array}{l}\text { Male, } \\
14.7 \text { years }\end{array}$ & $\begin{array}{l}\text { Male, } \\
16.4 \text { years }\end{array}$ & $\begin{array}{l}\text { Male, } \\
11.5 \text { years }\end{array}$ \\
\hline $\begin{array}{l}\text { Underlying } \\
\text { disease }\end{array}$ & None & Asthma & None & None & None \\
\hline $\begin{array}{l}\text { Disease } \\
\text { classification }\end{array}$ & Mild & Mild & Mild & Mild & Mild \\
\hline Initial symptom & Myalgia/fatigue & Dyspnea & Fever & Myalgia/fatigue & Myalgia/fatigue \\
\hline Treatment & None & None & None & None & None \\
\hline $\begin{array}{l}\text { Current } \\
\text { complaint }\end{array}$ & $\begin{array}{l}\text { Cough, chest } \\
\text { pain, palpitation, } \\
\text { myalgia/fatigue, } \\
\text { fear of not being } \\
\text { able to breathe } \\
\text { and pessimism }\end{array}$ & $\begin{array}{l}\text { Dyspnea, } \\
\text { myalgia/fatigue }\end{array}$ & $\begin{array}{l}\text { Myalgia/fatigue, } \\
\text { fear of going out, } \\
\text { sleep disorder }\end{array}$ & $\begin{array}{l}\text { Myalgia/fatigue, } \\
\text { fear of going out } \\
\text { and reinfection }\end{array}$ & $\begin{array}{l}\text { Myalgia/fatigue, } \\
\text { fear of going out } \\
\text { and reinfection }\end{array}$ \\
\hline $\begin{array}{l}\text { The day of } \\
\text { assessment after } \\
\text { the diagnosis }\end{array}$ & 130 & 105 & 139 & 118 & 116 \\
\hline
\end{tabular}

\section{Discussion}

In this study, the presence of possible longterm findings due to COVID-19 in children was investigated, and findings attributable to this infection were defined in five patients. The most commonly seen complaints were myalgia/fatigue. One remarkable result is that 
psychiatric problems were seen in four patients.

Long COVID is increasingly gained importance in the world that many organizations are at the stage of launch clinics and publishing clinical guidelines for it.15There is researches on how COVID-19 may influence children's lives but there is little information about children with long COVID.16,17On the other hand adult studies on long term effects of COVID 19 infection are increasing reported. In an adult study from Italy; 143 adults patients mostly diagnosed with pneumonia and hospitalised were assessed a mean of 60 days after onset of diseaese and only $18(12.6 \%)$ had no findings associated with COVID-19 while more than half of the patients experience three or more symtoms. Most frequently seen symptoms were fatigue, dyspnoea, joint pain, chest pain, cough and anosmia. In nearly half of the patient $(44.1 \%)$ described worsened quality of life. 18 In the evaluation of 384 hospitalized patients after a median of 2 months after discharge, 53\% reported breathlessness, 34\% cough and $69 \%$ fatigue while $14.6 \%$ had depression. In addition, it is reported that radiological abnormalities continue in a significant number of patients.19 Huang reported that at 6 months after symptom onset $\% 76$ of patients still had complaints. Fatigue or muscle weakness is the most commonly seen complaint that effected more than half of the patient. Sleep difficulties and anxiety or depression was reported nearly in $25 \%$ of patients. 20

Ludvigsson8 describes five pediatric patient with fatigue, dyspnoea and heart palpitations or chest pain that lasting for at least six months. In addition to these sypmtoms headaches, difficulties concentrating, depression, sleep disorders, miyalgia, dizziness, abdominal pain, diarrhoea and vomiting and also defined. Four of the five patients were girls and the median age was 12 year. Another important point of the article is that patients diagnosed with COVID-19 by their physician with no microbiological confirmation.

There are predictions that the pandemic will have many psychiatric effects on both people who are infected or not.21,22The reason for this is likely to be multifactorial that might include hospital admissions, drug use, social isolation, and the thought that many people lose their lives with the same diagnosis in the world. In the study, we showed the existence of psychiatric complaints in four children who did not have any before COVID-19, and two of them needed professional help from a child psychiatrist.

There are many uncertainties regarding risk factors for long-term COVID-19. There is a variety of data on which gender the postcovid-19 symptoms are seen more frequently. In the Carfi study mostly male affected $(62.9 \%)$ but there also studies that showed a higher percentage was observed in women.8,18,20,23 In our study approximately the same number of boys and girls affected (two girls, three boys). The fact that only one of our patients had an underlying disease 'asthma'and no comorbidity was detected in the other four patients is evidence that long COVID-19 can affect healthy children even in mild cases.

Our study has some limitations. Based on the retrospective study design, laboratory and radiological data was not available for all the patients. We were not able to reach all the parents by phone. Our results are based on the statements of the parents which may include recall bias. Only the findings that families think developed after the child had the COVID-19 infection are included. Our study was not sufficient to give prevalence for long COVID in the adolescent patient group because only asymptomatic, mild, and moderately affected patients were included, as post COVID symptoms may be affected by clinical severity of the disease.

Our exclusion of severe COVID-19 patients limits the generalization of our results. Besides, diagnostic scales were not used for sleep disorders and depression diagnoses.

\section{Conclusions}

To our knowledge, this study is one of the very few that focused on long term effect of COVID 19 in adolescents. Clinicians have focused much more on the period that the 
diagnosis was done but much more studies are needed to identify the prevalence, risk factors, clinical spectrum, and prognosis of long COVID in children to create a protocol on how and at what intervals these patients should be followed up. Also whether these patients will need rehabilitation in the long term is not clear at this time. Therefore, we

\section{REFERENCES}

1. Coronavirus disease (COVID-2019) situation reports 2021. Accessed April 17, 2021. https:// www.who.int/emergencies/diseases/novelcoronavirus-2019/situation-reports/

2. Li Q, Guan X, Wu P, et al. Early Transmission Dynamics in Wuhan, China, of Novel Coronavirus-Infected Pneumonia. $N$ Engl J Med. 2020;382:1199-1207.

3. Zimmermann P, Curtis N. Coronavirus Infections in Children Including COVID-19: An Overview of the Epidemiology, Clinical Features, Diagnosis, Treatment and Prevention Options in Children. Pediatr Infect Dis J. 2020;39:355-68.

4. Lazzerini M, Sforzi I, Trapani S, et al. Characteristics and risk factors for SARS-CoV-2 in children tested in the early phase of the pandemic: a cross-sectional study, Italy, 23 February to 24 May 2020. Euro Surveill. 2021;26:2001248.

5. Jiang L, Tang K, Levin M, et al. COVID-19 and multisystem inflammatory syndrome in children and adolescents. Lancet Infect Dis. 2020;20:e276e288.

6. Hertting O. More research is needed on the longterm effects of COVID-19 on children and adolescents. Acta Paediatr. 2021;110:744-745.

7. Feldstein LR, Rose EB, Horwitz SM, et al. Multisystem Inflammatory Syndrome in U.S. Children and Adolescents. $N$ Engl $J$ Med. 2020;383:334-346.

8. Ludvigsson JF. Case report and systematic review suggest that children may experience similar longterm effects to adults after clinical COVID-19. Acta Paediatr. 2021;110:914-921.

9. Dufort EM, Koumans EH, Chow EJ, et al. Multisystem Inflammatory Syndrome in Children in New York State. N Engl J Med. 2020;383:347358.

10. Guessoum SB, Lachal J, Radjack R, et al. Adolescent psychiatric disorders during the COVID-19 pandemic and lockdown. Psychiatry Res. 2020;291:113264.

11. Adolescent health in the South-East Asia Region. Accessed June 10, 2021.https://www.who.int/southeastasia/healthtopics/adolescent-health

12. Demirbilek Y, Pehlivantürk G, Özgüler ZÖ, et al. COVID-19 outbreak control, example of ministry of health of Turkey. Turk J Med Sci 2020;50(SI1):489- 94 . believe that our data will contribute suggestive information about the long-term problems these patients will face and how they should be followed up.

\section{Acknowledgements}

We thanked all patients and their parents who spared time and answered our questions.

13. Dong $\mathrm{Y}, \mathrm{Mo} \mathrm{X}, \mathrm{Hu} \mathrm{Y}$, et al. Epidemiological characteristics of 2143 pediatric patients with 2019 coronavirus disease in China. Pediatrics. 2020.

14. Ikincioğullari A, Kendirli T, Doğu F, et al. Peripheral blood lymphocyte subsets in healthy Turkish children. Turk J Pediatr. 2004;46:125-30.

15. The Lancet. Facing up to long COVID. Lancet. 2020;396:1861.

16. Ghosh R, Dubey MJ, Chatterjee S, et al. Impact of COVID -19 on children: special focus on the psychosocial aspect. Minerva Pediatr. 2020;72:226-35

17. Cao W, Fang Z, Hou G, et al. The psychological impact of the COVID-19 epidemic on college students in China. Psychiatry Res. 2020;287:112934.

18. Carfì A, Bernabei R, Landi F; Gemelli Against COVID-19 Post-Acute Care Study Group. Persistent Symptoms in Patients After Acute COVID-19. JAMA. 2020;324:603-5.

19. Mandal S, Barnett J, Brill SE, et al. 'LongCOVID': a cross-sectional study of persisting symptoms, biomarker and imaging abnormalities following hospitalisation for COVID-19 [published online ahead of print, 2020 Nov 10]. Thorax. 2020;thoraxjnl-2020-215818.

20. Huang $\mathrm{C}$, Huang L, Wang $\mathrm{Y}$, et al. 6-month consequences of COVID-19 in patients discharged from hospital: a cohort study. Lancet. 2021;397:220-32.

21. Marques de Miranda D, da Silva Athanasio B, Sena Oliveira AC, et al. How is COVID-19 pandemic impacting mental health of children and adolescents? Int J Disaster Risk Reduct. 2020;51:101845.

22. Meherali S, Punjani N, Louie-Poon S, et al. Mental Health of Children and Adolescents Amidst COVID-19 and Past Pandemics: A Rapid Systematic Review. Int $J$ Environ Res Public Health. 2021;18:3432.

23. Davido B, Seang S, Tubiana R, et al. PostCOVID-19 chronic symptoms: a postinfectious entity? Clin Microbiol Infect. 2020;26:1448-49. 